Library Review, 47 (3), 1998, 152 - 159. [ISSN 0024-2535] [online]:

http://www.emeraldinsight.com/Insight/viewPDF.jsp?Filename=html/Output/Published/EmeraldFullTextArticle/ Pdf/0350470301.pdf [Accessed 26 June 2008] Also translated into Portuguese by Patricia Zeni Marchiori , and published in Brazil as: Desafios para o desenvolvimento profissional na "sociedade da Informação": algumas respostas das Escolas de Biblioteconomia e Estudos de Informação na Grã-Bretanha. Informação \& Informação, Londrina, 3 (2), jul/dez. 1998, 7-18

\title{
CHALLENGES IN DEVELOPING PROFESSIONALS FOR THE 'INFORMATION SOCIETY' - and some responses by the British Schools of Librarianship and Information Studies
}

\author{
Ian M. Johnson
}

School of Information and Media, The Robert Gordon University, Aberdeen AB24 5BN (i.m.johnson@rgu.ac.uk)

\begin{abstract}
This paper identifies six major challenges facing the information profession as the 'Information Society' emerges: assisting users to deal with information overload; the high level of technical skills required to manage the new Information and Communication Technologies; the competition with other professions for the management positions in converged library, information and computing services; the need to incorporate a broader range of knowledge and skills, drawn from those traditionally seen as separate sectors of the information industry such as publishing; the need to develop a higher level of skills in teaching and facilitating the use of information; and the need for a greater ability to work with other people. It points to some solutions which have been adopted by Schools of Librarianship in Britain, many of them involving collaboration with other disciplines to produce the required depth of knowledge. It also calls for changes in the Schools' approach to teaching, learning, and research, and in the practitioner community's support for education in general and continuing professional development in particular. Finally, it points to the dangers of inertia.
\end{abstract}

\section{Introduction}

The emerging 'Information Society' and the changing role of information professionals is a matter of great concern throughout the world. This paper begins by summarising the developments which have contributed to the emergence of the 'Information Society', to briefly provide a context for the remainder of the paper. Then it identifies some of the challenges the 'Information Society' presents to librarians and information scientists. Finally, it suggests some of the things we need to do to prepare ourselves for the future and indicates some of the developments which are taking place in professional education in Britain.

\section{The Information Society}

We are probably all familiar with the concept of the 'information explosion', the phenomenal growth in published information which has taken place during the Twentieth Century, and 
particularly in the last 50 years. This has been facilitated by improving printing technologies, and stimulated by the growth of scientific and technical research, the spread of universal education, and growing prosperity. The publishing industries of the world have rapidly increased their output in terms of the number of books and journals published. In Britain alone, for example, the number of book titles published has increased over the last 40 years from about 20,000 each year to around 100,000 (RICHARDSON and BIRN, 1997)

We are all also well aware of the growth of Information Technology. Since the IBM PC was first introduced less than 20 years ago, we have witnessed remarkable changes - not least from a situation in which people were expected to organise their work according to what the computer could do, to one in which increasingly the computers are so powerful yet simple to operate that they can be trained to do what people want them to do.

There are also now a wide variety of communication technologies and standards available and under development. The speed with which they can carry information in electronic formats is increasing dramatically. To illustrate what these communication speeds represent in practical terms, consider the different times it would take to send in an electronic format over different communication links the contents of the entire version of the Encyclopaedia Britannica (approximately 24 large volumes in its printed form). To send it into your home through a conventional telephone system would take about one week of continuous transmission. To send it into your home using the same telephone line but with the latest transmission systems would take less than 3 seconds (MURDOCH, 1997).

These developments in Information and Communications Technologies have encouraged the growth of the Internet, and increasingly, libraries are being linked to this "Information Superhighway". In Europe, it is estimated that the number of Local Area Networks is increasing by $20 \%$ each year, and increasingly these are being connected to the Internet (EUROPEAN COMMISSION, 1995). Further developments in the operating speeds of both computers and telecommunications systems, and a continuing expansion of the Internet are likely to occur in the next few years, and will clearly facilitate the almost instantaneous transmission of huge quantities of data or images. This will transform the provision of information services in ways which we are only just beginning to imagine.

What is emerging from all this change and development is a growing awareness of the role which information does and could play in modern society - in economic, educational, and social development. It is no longer simply the librarians and publishers who are saying this. It is now widely appreciated by governments (GREAT BRITAIN, 1996) and by business leaders (HAWLEY COMMITTEE, 1996). It is leading to major financial investments and to serious consideration of the legislative framework which surrounds the information and communication industries.

\section{The new information professional}

Against the background of the growing recognition of the potential of Information and Communication Technologies, and of the value of information in every aspect of human development, there is a growing awareness that the nature and volume of contemporary information provision presents new challenges and call for new knowledge and skills. 
Other occupational groups within the industry are being as profoundly affected by these changes as the information service professional. Authors no longer need the support of publishing companies and booksellers because they can distribute their work through the World Wide Web. What then is the future role of the publisher? Industrial corporations are taking the view that they can add value to the industry's products by marketing them to different users in many different formats - in print, on Compact Disk, on-line, in video, or broadcast, on cable, or by satellite - and they are creating unified business organisations for that purpose(GREAT BRITAIN, 1983). How many of the employees engaged in these activities have more than a limited perspective on the industry and a narrow knowledge and skills base? It is arguable that because the information service professional plays a central role in the industry, and has a well-established and broad educational framework, they are well placed to expand their role in society.

However, although the electronic library environment has gradually emerged over a thirty year period, the investment costs of developing an electronic environment, and the lack of user friendliness of many electronic information products, have inhibited their introduction in libraries. Moreover, although publishers have been taking advantage of the technology to support the production of print based material, through for example computerised type-setting and page layout and through the use of teleworking, until recently relatively few have engaged in the distribution of their products in electronic formats. Interest in electronic publishing and the electronic library environment has generally only been stimulated in the last few years, notably by the development of CD-ROM technology and by increased access to the Internet. There is, consequently, limited experience in the existing professional workforce of the knowledge and skills required to enable them to play an effective part in the 'Information Society'.

State of the art reviews continually point towards the need for information professionals to be increasingly well-equipped with relevant Information Technology skills. The European Commission's Information Market Observatory reports, for example, summarise the spread of the technology and comment briefly on the need for improved teaching in the field, but say nothing about actual developments in educational provision in the field (EUROPEAN COMMISSION, 1995). There is also no shortage of recently published papers that emphasise the importance of professional education in the field of information and communication technologies, and that, at the same time, offer critical opinions on the apparent lack of progress by the Schools of Librarianship and Information Studies. For example, a recent guest editorial comment in 'Education for Information' challenged the Schools to ask themselves whether they were producing students with up to date and relevant knowledge and skills (MAHON 1996). These critics are frequently ill-informed. The professional literature generally pays considerable attention to the development of new technological applications, but provides only a limited overview of the implementation of these in the teaching departments. Clearly the educators must make greater efforts to inform the practitioner community about their efforts to keep the curriculum up-to-date and relevant (JOHNSON, 1997)

But, what new knowledge and skills are necessary?

Firstly, the problems presented to decision makers by information overload have become increasingly significant in recent years (WADDINGTON, 1996). Decision makers do not have the time to search for information, and require professional support by people who can undertake the task efficiently and effectively. Selectivity and screening of information is seen 
as being of growing importance. In the fields of business management, health care, and public policy making, there is a growing demand for individuals with the specialised skills required to address these problems (MOORE, 1987). These skills are an understanding of research and assessment techniques, the ability to prepare an analysis of the literature, and, perhaps critically, the ability to appraise and evaluate the information in the literature.

Secondly, as a result of the increased application of IT to information provision, the job of a library or information service professional is more than likely to involve activities of a highly technical nature, requiring knowledge and understanding not just of traditional practice in information management, but also of the latest technological developments. Employers now require staff with a thorough grounding in the necessary technical knowledge, and relevant managerial expertise and practical abilities (JOHN FIELDEN CONSULTANCY, 1993).

Third. There is no doubt that information is becoming a complex and expensive commodity. The recognition that information is a major asset has compelled many organisations to look at the way in which they manage their information systems and services. There is an increasing tendency - in industrial and commercial organisations, in government departments, in hospitals, and in universities (JOINT FUNDING COUNCILS, 1993) - for computer systems, telecommunications, archival and filing systems, libraries and information services to be managed as a single unit. In competing for these jobs with highly qualified technical and communications specialists, the modern information professionals must also be thoroughly professional managers. Information professionals are needed who can operate cost-effective and cost-efficient services, who are receptive to new ideas, who are familiar with the legal and ethical issues surrounding information provision, who can adapt their service to the changing needs of the organisation, and who can continually demonstrate the value of the information service to the achievement of the organisation's aims.

Fourth. In the coming age of electronic information, what skills are needed to manage a successful site on the World Wide Web - the librarian's skills in organising information, or the publisher's skills in marketing it, or a mixture of the two? If we take a strategic view of the workforce across the whole of the information and communication industry, it is evident that the people who work in it could and should share a common base of knowledge and skills, although their specialist expertise - and their aims and attitudes - do differ (JOHNSON, 1997).

Fifth. The task of teachers at all levels of education is primarily to transfer to their pupils the skills of acquiring and using information. There appears to be a lack of skills and confidence to make effective use of information by teachers (WILLIAMS, 1997). If information professionals are to play a more significant part in a 'learning society', they must have well developed training and facilitating skills, to help people to use not only libraries but also information sources in any of the new media.

Sixth, and finally. Alongside these practical skills, there is also a growing recognition that to play an effective role within organisations, information professionals will need the right attitudes and personal qualities: good interpersonal skills, leadership skills, and an understanding of user empowerment (LEVY, 1992).

\section{Some solutions?}


How then should these new skills be developed, and by whom? Let us now try to address each of these issues, and explain some of the developments which are taking place.

By way of introduction, it is important to explain that what the educators have to do is not only to reflect the changes taking place in the profession's knowledge base, but also to keep in step with changes in the job market. Demand for many of the specialist skills needed in any of the emerging sectors of the job market is, initially, so small that a separate course could not be viable. Inevitably, trying to cater for specialist needs within a single, generalist programme which tries to prepare students for a variety of employment opportunities may fail to satisfy both students or employers - but that is what is necessary in an evolving situation, although the opportunity for students to carry out independent study and research within the framework of the overall programme can offset this problem to a limited extent. Some of the criticism the Schools of Librarianship and Information Studies have faced in recent years, as the pace of change has accelerated, is perhaps because they have had to teach a little about each of these emerging new specialisms within the framework of a generalist programme of study.

But this does not mean that the Schools of Librarianship have not been looking for opportunities to develop specialist programmes.

There is a growing appreciation of the consequences of having more information than can be easily used, and of the need for more specific information systems and to apply the techniques of filtering information from different sources. Much of the information needed by decision makers exists in non-traditional formats, for example within an organisation's records of its own activities (HARE., 1996). The volume of information produced internally is often greater than that which has to be acquired from external sources. Managing these records so that the information can be retrieved when required can make a very cost effective contribution to decision making, and in many organisations there is a greater demand for Records Managers than there is for librarians. The size of this job market led the University of Northumbria's School of Information Management to establish a Masters degree programme in Records Management.

More attention is also being given to teaching not only the skills needed to find information, but also the skills needed to evaluate, consolidate and repackage what is found into a more usable form (SARACEVIC and WOOD, 1981). Repackaging of analysed and evaluated information adds value to the information (TAYLOR, 1986), and has created many new - and well paid - jobs for professional researchers and information analysts (MOORE, 1988). The challenge for the Schools of Librarianship is whether a critical evaluation of the content of the information can be undertaken without some insight into the way in which the information will be used. Who will provide librarians with the subject knowledge, and an understanding of the decision making process in business and government. Collaboration with other disciplines was seen as the answer. It led to the introduction of a specialist Masters degree programme in Information Analysis by The Robert Gordon University (MARCELLA, 1994; JOHNSON, 1995). This recruits students who are already graduates in other disciplines, and is taught in collaboration with the Business School and the School of Public Administration and Law.

Information Technology provides the most obvious example of the nature of the evolution in educational provision. Recently, there have been a growing number of advertisements for jobs in libraries and information services which have called for a high level of technical knowledge about the computing and telecommunications applications used in libraries and 
information services. For more than twenty years the Schools of Librarianship have been incorporating aspects of Information Technology applications into their teaching. Only now is the job market seen to be strong enough to support specialist courses.

The question then arises as to whether the necessary knowledge and skills can be taught to an adequate level by teachers who themselves do not have a deep technical understanding of Computer Science and Electronic Engineering? Should libraries seek to recruit graduates from those disciplines? it likely that they would be able to do so? Would graduates from those disciplines have sufficient understanding of information sources and information users?

The answer to those questions seems obvious to the Schools of Library and Information Studies. The future, again, lies in collaboration with the other disciplines. From 1997, we shall see at least two of the British Schools offering Masters degree programmes specialising in this area, The Robert Gordon University and Sheffield University. In Aberdeen, the programme in 'Electronic Information Management' will have substantial inputs from two other Schools in the University, Electronic Engineering and Computer Science, and has a strong focus on hardware (URL). The Sheffield programme in Information Systems will also be the result of collaboration with the University's Department of Computer Science. It is interesting to note that University managers are not unaware of these trends. One British University, Brighton, has reorganised its Computer Science Department, and half of it has recently been placed under the direction of the School of Librarianship.

Who will be the managers if computer services are merged with library and information services?

- the IT managers, who understand the technology and control large budgets, but who know little about information and its uses?

- the specialist managers, who know a little about information sources in their field, but little about IT?

or

- the librarians, who have an understanding of IT and are fully familiar with information needs and sources in the organisation? (SMITH 1996)

There is no doubt that managers value information (HAWLEY COMMITTEE, 1996). The challenge for librarians is that to compete for the top jobs in converged services, they must be good managers, be seen to be good managers, and want to manage. If we wish to become part of management of the organisation at a strategic level, which is where information is most valued (ROWAT, 1986), librarians need to develop the skills to operate effectively at that level. Should we rely on librarians to take advanced courses in Business management? If so, who should lead them? Again, we see a pattern of collaborative provision emerging in Britain. For some years, Schools of Librarianship have contributed course units in Information Management to their Universities' Business Schools' MBA programmes. More recently Loughborough University's Department of Information and Library Studies has initiated an MBA programme in Information Management, with support from the Business School.

If we look at the range of educational provision for the information and Communication industry, we see a slightly different pattern emerging (JOHNSON, 1998?). Programmes in Publishing Studies have been started by four of the British Schools of Librarianship and Information Studies, and three of the British Schools have recently been assigned 
responsibility for all Communications and Media teaching in their Universities. In September 1998, a School of Publishing Studies will begin to offer a Bachelors degree programme in librarianship. Clearly, there is an emerging agreement on the common ground in these programmes. Again, however, underpinning all these developments are collaborative activities involving Schools of Business Studies and Schools of Design.

The development of the librarian's role as a teacher or facilitator of information use is one which remains more problematic. At the very basic level, librarians have traditionally been involved in demonstrating how their library and its catalogue are arranged, so that users can find books themselves. As we move into the 'Information Society', the task becomes, potentially, more complex (NETSKILLS, 1996). It also brings the role of the librarians closer to the role of the teachers. Educational provision for this new role is at an early stage of development, but an interesting debate is beginning to emerge as a result of experiments in training librarians to teach the use of electronic information in some of the British Universities. At the moment, the debate is inconclusive, but it will come as no surprise that there is some significant resistance to the deeper involvement of librarians in the teaching process. One might speculate that the root of this conflict lies in the fact that these experiments have taken place without the involvement of the specialists in Schools of teacher education.

In turning finally to the personal qualities required by the new information professional, it is necessary to concede that, regrettably, the Schools probably have not given enough attention to them until recently. The model for professional education in Britain has traditionally been based on the assumption that graduates will go to work in large library organisations However, it has been recognised that more of students now take their first job in organisations where they are the sole information professional, and their success depends on their personal qualities and 'political' skills. Some of the Schools of Librarianship and Information Studies have begun to revise their teaching methods to try to enhance skills such as project management, team-working and leadership, and to develop students' interpersonal skills, and skills in making oral presentations (JOHNSON and WILLIAMS, 1990; LEVY, 1992).

Another, related area in which many of the Schools need to develop is research activity. Research not only maintains teaching at a level appropriate for higher education; it is also essential for keeping the curriculum in line with the leading edge of current practice and for stimulating the interest of students in change. It is regrettable that many of the Schools are not actively involved in research activity, and that so few students have their minds trained to the highest levels through pursuing research studies. How else can we claim to be producing the future leaders of our profession if we are not stretching their intellects to the full?

\section{Concluding observations}

Looking to the future, we must clearly develop a new generation of information professionals who are willing and able to learn, who recognise the need for continuing their professional development, and who are motivated towards it. Because, at entry level, information work is a very practical discipline, the emphasis in the Schools of Librarianship and Information Studies has been largely on teaching and on developing technical competencies, rather than on developing students' ability to learn. Clearly, the teaching institutions have to consider not only the content of their courses, but also the impact of their teaching, learning and assessment methods in preparing the new information professionals. Experience to date 
suggests that the only way forward lies in initiating collaboration with other disciplines to produce professionals with a deeper knowledge of specialist fields. This is a challenge too important to avoid.

Most of the Schools' graduates can be expected to have a working life of 30 to 40 years. Lifelong learning will play a significant part in their continuing professional development. However, it is clearly essential that their initial professional education should provide a foundation of knowledge and understanding, which will stimulate a deep interest and involvement in telematics applications in the communication of information. This will require their teachers to be regularly updated on recent developments, and thus motivated to introduce them in their courses.

The emergence of the 'Information Society' also has clear implications for the existing workforce, who will need considerable and continual retraining. As the management expert Tom Peters has said, "The only job security lies in being more talented tomorrow than you are today". In the rapidly changing environment in which we now work, the ability to continually learn is essential. They will need not only to develop the necessary technical competences, but also to ensure that they are sufficiently well informed about the range of information resources which will be accessible by electronic means. They will need to be competent in using the technology, but it will be their competence in finding relevant information which will sustain their personal and professional credibility when dealing with users who may themselves be at least as competent in using the technology. However good their initial professional education has been, a period of isolation from a major collection of information sources can only reduce their familiarity with its potential.

Part of the response to that challenge will depend on the willingness of employers to recognise the need for continuing professional development, and to support it. Part will also depend on the attitudes and abilities of the individuals. For both employers and educators, these developments may imply the need for additional commitment and additional resources. However if, as a profession, we wish to have a greater influence on our own future and a more significant role in the Information Society, we will need the resources to produce a generation of professional leaders who are not merely competent, but who can also lead the changes which are taking place rather than react to them.

This is not solely an internal matter for the information professions. As a High Level group of Experts recently observed in a report to the European Commission:

"Further expansions of efforts to improve and match both demand and supply in ICT [Information and Communication Technologies] training are needed, at both member state and the EU [European Union] levels, through a combination of E\&T [Education and Training] policies with social, cultural and industrial policies.” (HIGH LEVEL EXPERT GROUP, 1996)

Clearly, some effort will be necessary to seek the support of governments to implement the necessary changes, and this will make significant demands on the political skills of the leaders of the profession.

Doing nothing is not an option. In a study of the survival of large corporations, Arnold de Geus, former Chief Strategist with the Royal Dutch/Shell Group, has recently identified the characteristics of those whose primary purpose is to survive and perpetuate themselves. The 
key factor contributing to their survival appears to be their ability to learn and to adapt to their environment more rapidly than their competitors (DE GEUS, 1997). Schools of Librarianship and Information Studies are not exempt from the risk of failure and collapse if the demand for their graduates ceases or is modified by changes in the job market (PARIS, 1991). The Schools need, above all, to accelerate their ability to grasp change, and in particular to release the innovative talents and energy of their staff to develop new programmes rapidly and regularly. Evidence to support this argument can also be found in two pan-European studies conducted in 1996, the PLIS study (THORHAUGE, 1996) and the Pro-train study (PORS and SCHREIBER, 1996), which indicated the need to launch initiatives to spread new ideas and disseminate research results.

These developments will require not only the understanding and consent, but also the active support of the practitioners. In the end, it is the practitioner community which will benefit.

"The final driver [of the development of the Information Society] is access to a supply of skilled ICT [Information and Communication Technologies] professionals. They are an essential element in a virtuous circle where skills attract investment which stimulates growth which in turn attracts more skilled professionals. This circle is essential to prevent migration of top talent to a more conducive environment." (SPECTRUM, 1996)

AUTHOR (WWW Homepage URL - http://www.rgu.ac.uk/schools/sim/staff/imj/imj.htm)

Ian Johnson has been Head of the School of Information and Media at The Robert Gordon University, Aberdeen, Scotland since 1989. Previously he was in charge of industry liaison and continuing education programmes at the College of Librarianship Wales; Assistant to the British Government's Advisers on library matters; and an operational manager in public libraries. He was Chairman of the IFLA Section on Education and Training from 1991 to 1993, and Chairman of the Professional Board of IFLA from 1993 to 1995. From 1993 to 1995 he was also Chairman of the (British) Library Association's Personnel, Training and Education Group. He is currently a member of the Council of The Library Association; of the Editorial Board of Education for Information; and Chairman of the Heads of Schools and Departments Committee of BAILER: the British Association for Information and Library Education and Research.

August, 1997

An earlier version of this paper was presented at seminars in the Pontificia Universidad Catolica del Peru, Lima, Peru, and Universidade Federal do Parana, Curitiba, Brazil, in July 1997.

\section{REFERENCES}

De GEUS, A. (1997) The living company: habits for survival in a turbulent business environment. U.S.A., Boston: Harvard Business School Press. 
EUROPEAN COMMISSION, IMPACT Programme (EC programme for the establishment of an information services market: Information Market Observatory. (1995) The main events and developments in the information market, 1993 - 1994: report from the Commission to the Council, the European Parliament and to the Economic and Social Committee. Luxembourg: Commission of the European Communities, Directorate General XIII: Telecommunications Information Market, and Exploitation of research.

GREAT BRITAIN. CABINET OFFICE. (1983) Information Technology Advisory Panel. Making a Business of Information: A Survey of New Opportunities. London: H.M.S.O.

GREAT BRITAIN, PARLIAMENT: HOUSE OF LORDS, Select Committee on Science and Technology. (1996) Information Society: Agenda for Action in the UK. London: HMSO HARE, C. E. (1996) Continuing professional development for the information discipline of records management. Part 1: Context and initial indications of current activities. Librarian Career Development, 4 (2), 1996, 22-7.

HAWLEY COMMITTEE. (1996) Information as an asset: the board agenda. London: KPMG IMPACT.

HIGH LEVEL EXPERT GROUP ON THE SOCIAL AND SOCIETAL ASPECTS OF THE INFORMATION SOCIETY. (1996) Building the European Information Society for us all: first reflections of the High Level Group of Experts. Interim Report, January 1996.

Luxembourg: European Commission, Directorate General V.

JOHN FIELDEN CONSULTANCY. (1993) Supporting expansion: a report on Human Resources Management in Academic Libraries for the Joint Funding Council’s Libraries Review Group, July 1993 (revised September 1993). Bristol: Higher Education Funding Council (England). ("The Fielden Report”).

JOHNSON, I.M. (1995) Making sense of research in business and government issues: the education and training of information analysts: paper presented to the workshop on 'Teaching research methods' arranged by the Section on Education and Training and the Section on Library Theory and Research during the I.F.L.A. conference, Istanbul, August 1995. (I.F.L.A. Conference papers ref. 184-SET(WS)-6/LTR-10-E)

JOHNSON, I.M. (1997) Peering into the mist and struggling through it - the education and training of the future information professional. Journal of librarianship and information science, 29 (1), March 1997, 3-7. (Editorial comment, based on a paper presented to the annual conference of EUSIDIC: the European Association of Information Services, Bologna, October 1996; also summarised in Newsidic, 131, November-December 1996, 23-24.)

JOHNSON, I.M. (1998?) Education for publishing - the British experience. Paper presented to the Conference 'The Book, Libraries, Publishers and Laws', organised by Zagreb Chamber of Commerce's Association of Publishers and Booksellers and the University of Zagreb’s Department of Information Science and, sponsored by the Cultural Policy and Action Division of the Council of Europe's Directorate of Education, Culture and Sport, December 1996, Zagreb. (in press)

JOHNSON, I.M., and WILLIAMS, D.A. (1990) The "enterprise culture" and curriculum development for librarianship and information studies. Personnel, training and education, 7 (2), 1990, 31-36.

Joint Funding Councils’ (HEFCE, SHEFC, HEFCW, DENI), Libraries Review Group: Report. 1993. Bristol: Higher Education Funding Council (England) - (“The Follett Report”)

LEVY, P. (1992) People skills: interpersonal skills training for library and information work. London: British Library. Library and Information Research Report

MAHON, Barry. (1996) Editorial. Education for Information, 14 (2), 1996, 83-84

MARCELLA, R.C. (1994) The development of a new Postgraduate Diploma/MSc course in Information Analysis at The Robert Gordon University in New worlds in information and 
documentation: proceedings of the forty-sixth FID Conference and Congress held in Madrid, Spain, 22-29 October 1992. Amsterdam: Elsevier. pp. 471-477.

MOORE, N. (1987) The emerging markets for librarians and information workers. London: British Library.

MOORE, N. (1988) Information-intensive management: impact on the employment market for information professionals. London: Aslib.

MURDOCH, J.W., and others . (1997) Developments in communications technology: an introduction for the non-technical reader. Audiovisual librarian: multimedia information, 23 (2), May 1997, 112-117.

NETSKILLS. (1996) Training the users. Ariadne, 2, March 1996, 9-10

PARIS, M. 1991. Library school closings: the need for action. Library Quarterly, 61 (3), July 1991, 259-262.

PORS, N.O., and SCHREIBER, T. (1996) Librarian training in Information and Communication Technologies: A study of needs and deliverables. Copenhagen: Danmarks Biblioteksskole. (EU Prolib/Train 10278)

RICHARDSON, P., and BIRN, R. (1997) European publishing training needs for the Information Society. London: Book House Training Centre (the EPTNIS report)

ROWAT, M. (1986) Industrial intelligence: the need for synthesis. Library Management, 7 (5), 1986, 29-36.

SARACEVIC, T., and WOOD J. (1981) Consolidation of information: a handbook on evaluation, restructuring and repackaging of scientific and technical information. Paris: UNESCO.

SMITH, J.M., and others. (1996) The Intelligent City: electronic information and its potential in the provision of health and safety information in the oil and gas industry. Aberdeen: The Robert Gordon University. (British Library Research and Development Department Report 6255)

SPECTRUM STRATEGY CONSULTANTS. (1996) Development of the Information Society: an international analysis - a report for the Department of Trade and Industry. London: H.M.S.O.

TAYLOR, R S. (1986) Value added processes in information systems. U.S.A., New Jersey: Ablex Publ. Corp.

THORHAUGE, J., and others. (1996) Public libraries and the Information Society. Study on behalf of the European Commission. DG-XIII/E/4. Copenhagen: Danmarks Biblioteksskole. (EU Prolib/PLIS 10340)

URL http://www.rgu.ac.uk/schools/sim/courses/courses.htm)

WADDINGTON, P. (1996) Dying for information: an investigation of information overload in the UK and worldwide. London: Reuters Business Information WILLIAMS, D.A., and others. (1997) Is there any knowledge out there? The impact of research information on practitioners. Aberdeen: The Robert Gordon University. (British Library R\&IC report) 